\title{
Brim, M. (2020). Poor Queer Studies: Confronting Elitism in the University. Duke University Press.
}

\section{Review by Renny Christopher}

The introduction of this essential new study of elitism in the U.S. university system is called 'Queer Dinners,' which, among other things, describes Brim's night students at the College of Staten Island getting their candy bar-and-chips dinners out of a half-empty vending machine. They eat in a decrepit classroom where Brim's attempts to get to the intellectual work of the class are thwarted by video projectors that don't work. Hallways flooded by broken pipes, no heat - these very real material conditions symbolize the distance between the rich, elite institutions where Queer Studies has been shaped and the poorly-funded public institutions that educate more than three-quarters of all students in higher education in the $21^{\text {st }}$ century. Or, as Brim puts it, 'the physical plant shapes how we're queer here' (p. 89). My experience of reading this book is, oh, yeah, I've eaten those dinners, I know their taste, the residue on my fingers and tongue.... I've taught in that same classroom, on the other side of the continent, at a rural California State University campus where I was allowed to develop an intro to LGBTQ studies course in the 1990s, but was warned that if I tried to offer it, it would never draw enough students and would be cancelled. It filled. And had a waiting list. And my students brought their vending-machine dinners to class with them. I imagine many readers of the Journal of Working-Class Studies have eaten those dinners as students and/or teachers in the classrooms of our (monetarily) poor institutions.

I think I've been waiting for this book since the day back in the 1990s when I sat in a session at the Modern Language Association meeting and heard Stanford English professor Marjorie Perloff say that we should return to teaching formal analysis of poetics because 'our students are hungry for it.' My jaw dropped on hearing that, because my students were just plain hungry and trying to get a degree that would get them a job that would feed them and theirs. Brim takes his experience teaching (literally) hungry students and uses it to question and re-think not only the field of queer studies from a poor/working-class perspective, but to question the very ways that the system of higher education in the U.S is arrayed not to dismantle, subvert, or ameliorate the class system, but to keep students sorted along class lines. About the field of higher education Brim writes: 'It is difficult to find an institution in the United States that sorts people by socioeconomic class as effectively as higher education; even as the university simultaneously proclaims and often fulfills its democratizing promise' (p. 4).

Brim's primary focus is on the ways that Queer Studies has developed (in terms of scholarship and pedagogy) almost exclusively in high-prestige, highly-selective institutions, and is therefore an exclusionary - and incomplete - field. He notes how Queer Studies positions itself against the grain, but if democratization is its goal then it has failed, in part because class as a category of analysis has not been part of Queer Studies. This book is what he calls a methodological intervention, seeking to create a field of Poor Queer Studies, based in black queer literacy, which comes out of poor institutions such as the College of Staten Island. He seeks 'to articulate the 
background logic for why and how one can and cannot write a book about Queer Studies from poor and working-class two-year and nonselective four-year institutions' (p. 33). To do so he writes about his experiences of teaching Queer Studies to queer and non-queer students, the majority of whom are working-class students of color. Incorporating teaching into theory-making is something we talk about a lot, but rarely do. I thought his chapter called 'Poor Queer Studies Mothers' was going to be about the foremothers he was calling upon for his theoretical foundations. I was delighted to find that the chapter is actually about his students who are literally mothers, including those who have to bring kids to class when their childcare arrangements fall through. Here's one particularly great example of how out of touch academic theory is with who our students are (because it is primarily produced in rich institutions): some women 'enroll in Poor Queer Studies classes in order to be better mothers to their queer and not-queer kids, or to better perform their duties at their low-paying community outreach jobs. Yet, impossibly, Queer Studies manages to talk about a divide between town and gown, ivory tower and real world, queer theory and lived experience' (pp. 138-9). This passage exemplifies one of the things about this book that speaks to me most strongly in our current moment - this is a compassionate book, a book written by someone who possesses enough humility to learn from his poor and working-class students, particularly those of color, and to put that learning at the center of a book that is ironically - as he points out himself — published by a high-end university press.

He raises questions that are really unraisable in a rich queer studies context in 'high-end' higher education institutions: 'What would it look like and what would it mean to intentionally teach Queer Studies to working-class students?' (p. 101); how 'might Queer Studies help students in the workplace' (p. 102) and why 'should Queer Studies be considered an applied field of study?' (p. 106). These questions are mind-blowing because they're so far outside the norms of the field of Queer Studies (or, for that matter, Working-Class Studies). Brim creates intersections by taking antipodal ideas and knocking them together, forcing thought bubbles to pop out of the collisions. He offers a provocative, practical, and inspiring (modeling myself on Brim, I am linking disparate or even antithetical terms) list of examples of what he (revolutionarily) calls 'vocational Queer Studies' which ends with 'the queerest question of all: What makes work straight?' (p. 107). That's a question I've thought a lot about, but never named in those terms; I appreciate his formulation of it.

Brim calls for something that has been much on my mind for the past several years. We need to stop thinking of higher education as being personified by the ivy plus tier, which represents a tiny fraction of the students in higher education today, and yet takes up nearly all the news coverage devoted to higher education. One of my colleagues told me recently about talking with a NYT reporter, trying to get the reporter to feature universities that educate the new majority, and the reporter said the Times covers elite universities because that's where their readers went. As Brim puts it, we 'can't stop looking at high-end education' (p. 148), even though poor schools might actually do some things better, which is, as he notes, a practically inconceivable idea (p. 93). (Those of us who have spent careers in poor schools might already know this.) His incisive critique of free college proposals in our 'steeply tiered' educational landscape is sobering, as is his question of 'why isn't the call among progressives, including queer progressive intellectuals, for equal public education for all?' (p. 197). Why, indeed. 
This book is important in multiple contexts - in Queer Studies, in working-class studies, and in the field of higher education looking at itself. One of the crucial parts of the book is that it insists on making race central to looking at all of the above, from noting the material absence of black male student bodies (p. 6), to proposing black queer remedial reading as a GE requirement, because, as he points out, no institution teaches black queer literacy; he calls it a cross-class, cross-status, cross-institution, cross-race problem. The book's final chapter centers both on a reading of John Keene's Counternarratives and on his students' experiences of learning to read it. Brim says that this text 'teaches us to read fiction that does not depend narratologically on the underlying storytelling principles of anti-blackness and anti-queerness' (p. 169-70). Just so, Brim's text shows us a Queer Studies discipline - and a University — which does not depend on the underlying principles of anti-working-classness. So, how do those of us who have eaten the poor queer dinners get those who are eating banquets in rich institutions to read the book?

\section{Reviewer Bio}

Renny Christopher is Vice Chancellor of Academic Affairs at Washington State University Vancouver. A Carpenter's Daughter: A Working-Class Woman in Higher Education (Sense Publishers, 2009), addresses xyr experiences as the first in xyr family to attend college. Before earning a doctorate, Christopher worked as a printing press operator, typesetter, carpenter and horse wrangler. 